\title{
FENOMENA SHOUSHIKA DI JEPANG : PERUBAHAN KONSEP ANAK
}

\author{
Oleh: \\ Arsi Widiandari \\ Program Studi Bahasa dan Sastra Jepang, Universitas Diponegoro, \\ Jl. Prof. Soedarto, SH, Kampus Undip Tembalang, Semarang, Indonesia 50275
}

\begin{abstract}
The focus of this study is the shoushika phenomenon or decrease in the number of births that occurred in Japan from the perspective economic household in raising children. The research data was collected from several sources of statistical data published by the Japanese government, Family Income and Expenditure Survey, and National Institute of Population and Social Security Research.

Recently the delay of childbearing of young married couple is said to reason of fertility decline. The high cost of children is said to be one of the causes of this delay. This paper will focus on the persistent low birthrate in Japan and the change of utility of children in Japan's family. This paper show that there's a transition from traditional family to modern family that influence change of children utility from good utility become comsumption utility. The transition to consumption utility related to Japanese family expenditure especially what family give to their children.
\end{abstract}

\section{PENDAHULUAN}

Dalam beberapa dekade terakhir, Jepang dihadapi pada masalah yang berhubungan dengan kondisi demografi. Hal tersebut disebabkan karena terus terjadinya penurunan jumlah kelahiran dan pesatnya pertumbuhan populasi lansia. Akibatnya, struktur demografi Jepang menunjukkan kondisi masyarakat menua atau koreika shakai. Rendahnya pertumbuhan kelahiran di Jepang menjadi sorotan dari beberapa pengamat demografi, media massa baik yang berada di Jepang maupun yang berada di luar Jepang. Hal ini disebabkan karena pertumbuhan populasi penduduk alami hanya akan terjadi jika tingkat kelahiran lebih besar dibandingkan dengan tingkat kematian.

Fenomena menurunnya jumlah kelahiran di Jepang telah terjadi sejak tahun 1975, yang kemudian dikenal dengan nama shoushika, yang berasal dari huruf kanji [ 少 ] = sedikit, [子 ] = anak, dan [ 化 ] = perubahan. Sehingga shoushika dapat dirumuskan sebagai kondisi pada saat jumlah kelahiran mengalami perubahan menuju jumlah yang lebih sedikit. Masahiro Yamada dalam bukunya yang berjudul Shoushika Shakai Nihon mengatakan bahwa shoushika adalah keadaan menurunnya jumlah anak yang dilahirkan (Yamada, 2007: 3).

Pasca Perang Dunia II jumlah kelahiran di Jepang mengalami pasang surut, sejak tahun 1975 angka tersebut terus mengalami penurunan sampai saat ini dan diperkirakan jumlahnya akan terus menurun. Sementara, tersedianya sumber daya manusia sangat berkaitan erat dengan pertumbuhan populasi, khususnya jumlah kelahiran. Jumlah kelahiran merupakan faktor yang dapat menentukan jumlah usia produktif yang berfungsi sebagai pengganti generasi sebelumnya. Penghitungan rata-rata kelahiran disebut dengan istilah TFR atau Total Fertility Rate yang merupakan estimasi dari rata-rata jumlah kelahiran nyata dari satu orang wanita seumur hidupnya (Ochiai, 1997: 38 ).

Grafik 1. Jumlah Kelahiran di Jepang (19472007)

\footnotetext{
${ }^{*}$ Penulis Korespondensi.

E-mail: arsi901@gmail.com
} 
Tersedia online di http://ejournal.undip.ac.id/index.php/izumi

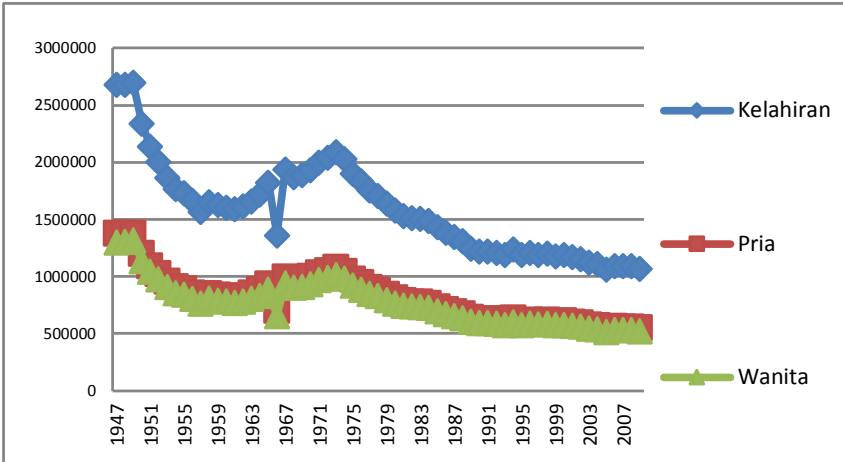

Sumber : National Institute of Population and Social Security Research

Grafik di atas memperlihatkan perkembangan jumlah kelahiran di Jepang yang mengalami kenaikan dan penurunan. Baby boom pertama terjadi pasca PD II yaitu tahun 1947-1949. Pada tahun ini pemerintah menerapkan peraturan berkaitan dengan perencaaan keluarga, dan sejak tahun 1949 jumlah kelahiran mengalami penurunan dengan alasan meningkatnya aborsi dengan alasan meningkatkan kualitas hidup. Baby Boom kedua muncul tahun 1971-1974, pada masa ini masyarakat Jepang berada di puncak kemakmuran dan tidak memiliki kenangan akan perang. Kemudian sejak tahun 1974 jumlah kelahiran mengalami penurunan berkaitan dengan perubahan gaya hidup.

Dalam penelitian yang telah dilakukan sebelumnya, pernikahan sering disebut sebagai faktor utama yang menentukan jumlah kelahiran, diantaranya adalah meningkatnya fenomena bankonka ${ }^{1}$ dan jumlah populasi dari orang yang tidak menikah (Ueno,1998; Retherford et al,1996 ; Ogawa,2003). Penelitian ini akan mencoba membahas mengenai Shoshika yang berkaitan dengan perubahan konsep anak dalam keluarga Jepang.

\subsection{Rumusan Masalah}

Berdasarkan latar belakang masalah yang telah dijabarkan sebelumnya, maka rumusan masalah pada penelitian ini adalah

\footnotetext{
${ }^{1}$ Bankonka disebut juga kekkon moratoriamuka (dalam bahasa inggris moratorium) yang berarti gejala penundaan pernikahan.
}

bagaimana fenomena Shoushika yang terjadi di Jepang dilihat dari perubahan konsep anak, khususnya berkaitan dengan biaya yang dikeluarkan oleh keluarga dalam membesarkan seorang anak.

\subsection{Tujuan Penelitian}

Berdasarkan rumusan masalah tersebut, maka tujuan dari penelitian ini adalah untuk mengetahui:

1. Latar belakang fenomena Shoushika

2. Faktor ekonomi yang mempengaruhi terjadinya perubahan konsep anak dalam masyarakat Jepang.

\subsection{Landasan Teori}

Penelitian ini menggunakan landasan teori ekonomi fertilitas yang dipaparkan oleh Leibenstein, yakni kajian ilmu yang melihat faktor ekonomi yang mempengaruhi angka kelahiran.

Leibenstein mengungkapkan bahwa terdapat tiga konsep anak. Konsep pertama adalah anak sebagai sumber produksi yang bertujuan untuk mendukung pendapatan keluarga, hal ini umumya terjadi pada masyarakat pertanian yang mengandalkan manusia sebagai tenaga kerja. Konsep kedua adalah anak sebagai konsumsi. Konsumsi yang di maksud adalah segala bentuk pengeluaran keluarga yang dibutuhka untuk membesarkan anak. Konsep anak yang ketiga adalah anak sebagai sumber kenyamanan, yang sangat erat kaitannya dengan kebutuhan orang tua untuk bergantung pada anak mereka ketika memasuki usia lanjut. Hal ini disebabkan karena pada usia lanjut, seseorang sudah tidak lagi dikategorikan sebagai usia produktif.

\section{PENURUNAN JUMLAH ANAK DI JEPANG}

Shoushika adalah istilah yang digunakan dalam menggambarkan penurunan jumlah kelahiran di Jepang. Kata shoushika pertama kali muncul di tahun 1992, dalam sebuah judul White Paper yang dikeluarkan oleh pemerintah Jepang yang berjudul 
Shoushi shakai no tourai, sono eikyou to taisaku (Masahiro, 2007: 3). Fenomena ini baru menjadi perhatian bagi pemerintah dan media massa pada tahun 1989, ketika TFR Jepang mencapai angka terendah pada saat itu yaitu 1,57, di bawah TFR pada tahun 1966 yaitu 1,58, peristiwa tersebut kemudian dinamakan dengan " 1,57 shock" (Ogawa, 1993: 703).

Kono menjabarkan shoushika sebagai berikut:

少子化とは、新旧時代の間で 1 対 1 の人 口の置換えができなくなる低い出産率が 継続することを言。

Terjemahan: Shoushika adalah tingkat kelahiran yang terus menurun, sehingga antara generasi satu dengan generasi yang lain kehilangan populasi pengganti (Kono,2007:1)

Dengan kata lain, shoushika adalah keadaan terus menurunnya jumlah kelahiran sehingga menimbulkan hilangnya populasi dari generasi muda yang akan melanjutkan kehidupan dari generasi yang terlebih dahulu.

Sejak pertengahan tahun 1970-an jumlah kelahiran di Jepang telah menurun secara stabil dan terus terjadi sampai dengan beberapa tahun terakhir. Penurunan jumlah kelahiran yang terjadi di Jepang terjadi bukan tanpa alasan melainkan telah mengalami suatu proses yang panjang. Saat ini Jepang telah menjadi negara dengan jumlah kelahiran yang sedikit, dan diiringi dengan tingginya jumlah usia lansia (Ozawa, 1995: 4).

Proses panjang tersebut meliputi perubahan masyarakat Jepang yang semula merupakan masyarakat pertanian menjadi masyarakat industri, sehingga anak yang semula adalah sumber tenaga kerja keluarga yang mempunyai nilai produksi, berubah menjadi konsumen yang harus difasilitasi dengan disediakannya kesehatan dan pendidikan yang layak.

Selain itu, adanya generasi shinjinrui atau disebut dengan generasi baru, adalah mereka yang lahir pada era tahun 1960-an dan setelahnya. Mereka tumbuh dalam masyarakat Jepang ketika Jepang tengah berada pada periode pertumbuhan ekonomi dan menikmati keuntungan saat berada di usia 30 tahun. Wanita yang terlahir dalam era ini mempunyai pikiran bahwa melahirkan dan menghabiskan uang untuk pendidikan anak merupakan suatu kerugian ekonomi.

Dengan semakin menurunnya jumlah kelahiran bayi yang terjadi sejak pertengahan tahun 1970-an sampai dengan saat ini, hasilnya adalah komposisi demografi yang telah berubah menjadi masyarakat menua ${ }^{2}$. Pada tahun 1950, jumlah anak yang lahir sebanyak 35,4\% sedangkan pada tahun 2003 jumlahnya turun menjadi $14 \%$, sementara populasi manula naik menjadi 19\%, jika terlalu sedikit anak yang dilahirkan, maka akan mengakibatkan ketidakstabilan komposisi demografi (Coulmas, 2008:5). Grafik 2. Komposisi Demografi Jepang 1950,2009, dan 2050 (Proyeksi)

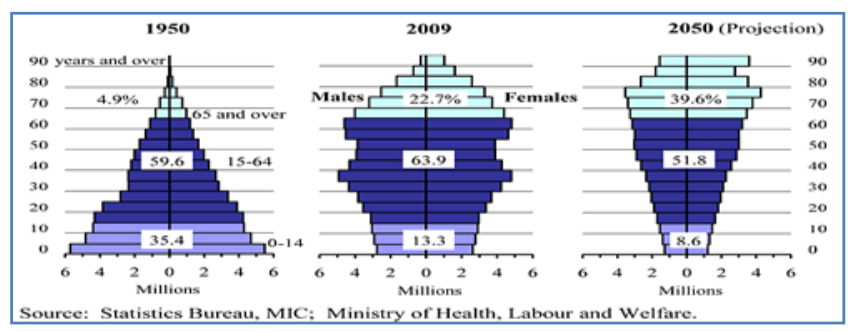

Gambar di atas merupakan piramida populasi yang merupakan gambaran dari komposisi penduduk di Jepang yang terbagi dalam tahun 1950, 2009 dan 2050 (proyeksi). Pada piramida pertama dapat terlihat bahwa populasi anak yang lahir sampai dengan usia 14 tahun lebih besar jika dibandingkan dengan populasi usia produktif (15 sampai dengan 64 tahun), dan populasi usia lansia (65 tahun keatas). Sedangkan pada piramida kedua, yang menggambarkan kondisi di tahun 2009, terlihat bahwa mayoritas merupakan populasi usia produktif yaitu sebanyak 63,9\%. Jika dibandingkan dengan piramida sebelumnya, populasi usia 0 sampai 14 tahun telah mengalami penurunan jumlah dari 35,4\% di tahun 1950 menjadi 13,3\% di tahun 2009.

\footnotetext{
2 Dalam bahasa Jepang, konsep ini disebut dengan Koreika-Shakai (aging society), yaitu ketika struktur demografi menunjukkan bahwa jumlah manula lebih besar dibandingkan dengan jumlah kelahiran bayi.
} 
Dalam kondisi yang tergambar pada piramida kedua, Jepang sebenarnya masih dapat bertahan, hal ini dikarenakan proporsi usia produktif lebih besar jika dibandingkan dengan populasi usia non-produktif. Akan tetapi, mengingat kecenderungan bahwa jumlah kelahiran terus mengalami penurunan, maka dikhawatirkan kondisi yang terjadi di masa mendatang akan semakin memburuk seperti yang terlihat pada piramida ketiga.

\section{JUMLAH KELAHIRAN IDEAL DAN JUMLAH KELAHIRAN NYATA}

Rendahnya jumlah kelahiran memberikan kekhawatiran, hal tersebut disebabkan Jepang cenderung memperlihatkan bahwa jumlah kelahiran tidak mengalami kenaikan. Meskipun pada tahun 2006 dan 2007 jumlah TFR mengalami kenaikan, namun jumlahnya tidak signifikan dan masih berada di bawah standar. Untuk menjaga keseimbangan jumlah populasi, maka diperlukan jumlah ideal anak di setiap keluarga. Jumlah kelahiran ideal memberikan gambaran bahwa dengan jumlah tersebut negara akan mencapai komposisi demografi yang stabil dan menjamin akan terus tersedianya populasi usia produktif yang ditandai dengan jumlah kelahiran bayi.

Meskipun telah ditetapkan jumlah kelahiran ideal bagi setiap keluarga, namun masih terdapat jarak antara jumlah tersebut dengan jumlah kelahiran nyata. Kenyataan tersebut menunjukkan bahwa masyarakat Jepang cenderung memilih untuk memiliki anak dengan jumlah yang sedikit.

Tabel 1. Jumlah Kelahiran Ideal dan Kelahiran Nyata

Sumber: National Institute of Population and Social Security Services Research

\begin{tabular}{|l|rrrrrrr|}
\hline & 1977 & 1982 & 1987 & 1992 & 1997 & 2002 & 2005 \\
\hline Ideal Number (1) & 2.42 & 2.49 & 2.51 & 2.4 & 2.33 & 2.31 & 2.3 \\
Actual Fertility & 1.8 & 1.77 & 1.69 & 1.5 & 1.39 & 1.32 & 1.26 \\
Rate (2) & 0.62 & 0.72 & 0.82 & 0.9 & 0.94 & 0.99 & 1.04 \\
Difference (1-2) & 0.62 &
\end{tabular}

Dari grafik di atas dapat terlihat bahwa jumlah kelahiran nyata terus mengalami penurunan, dan berada di bawah jumlah kelahiran ideal sejak tahun 1977 sampai dengan tahun 2005. Berdasarkan data terbaru yang diterbitkan oleh Cabinet Office di tahun 2011, jumlah kelahiran nyata telah jauh berada di bawah jumlah kelahiran ideal, yakni 1,2 per wanita dengan jumlah kelahiran ideal yakni 2,3 (Naikakufu, 2011). Angka tersebut menunjukkan bahwa terdapat jarak antara jumlah kelahiran ideal dengan jumlah kelahiran nyata, yang disebabkan oleh adanya beberapa faktor pendukung sehingga masyarakat Jepang memilih untuk memiliki anak dengan jumlah yang sedikit, yang akhirnya menjadi latar belakang terjadinya shoushika.

\section{PERUBAHAN KONSEP ANAK}

Fenomena Shoshika haruslah dipandang dari beberapa sudut pandang. Selain meningkatnya fenomena Bankonka yang seringkali dikaitkan dengan menurunnya jumlah kelahiran di Jepang, penurunan jumlah kelahiran juga berkaitan dengan berubahnya konsep anak dalam keluarga Jepang. Perubahan konsep anak ini sering terkait dengan perubahan keluarga dari tradisional ke keluarga modern. Dalam mengkaji masalah kelahiran yang dilihat dari sudut pandang ekonomi rumah tangga, Leibenstein memapaparkan mengenai pembagian konsep anak. Leibenstein membagi konsep anak dalam tiga bagian, yaitu anak sebagai sarana produksi, anak sebagai barang konsumsi dan anak sebagai sumber kenyamanan.

\subsection{Anak Sebagai Sarana Produksi}

Konsep ini lahir dari kondisi
masyarakat yang masih merupakan
masyarakat agraris atau masyarakat yang
mengandalkan pendapatan mereka dari hasil
pertanian. Kondisi demikian merupakan
cerminan dari masyarakat Jepang tradisional.
Masyarakat pertanian umumnya
membutuhkan tenaga kerja yang berasal dari
anggota keluarga tersebut, dengan demikian,


keberadaan seorang anak dalam keluarga mempunyai nilai produksi sebab berkaitan dengan ketersediaan tenaga kerja yang akan membantu produktivitas perekonomian keluarga. Ciri khas masyarakat petani tradisional adalah tinggal dalam keluarga besar yang terdiri dari setidaknya tiga generasi, dan tinggal di daerah pertanian yang mengandalkan hasil tani sebagai sumber pendapatan mereka.

Hal ini tentunya berbeda dengan yang terjadi pada masyarakat Jepang modern, yang telah berganti menjadi masyarakat industri. Masyarakat mulai meninggalkan mata pencaharian di bidang pertanian dan masuk ke dalam industri yang tidak lagi membutuhkan banyak tenaga kerja.

Struktur keluarga pada masyarakat Jepang pun telah berubah dari masyarakat agraris menjadi masyarakat industri, yang terlihat dari meningkatnya jumlah keluarga batih, di sisi lain jumlah keluarga yang terdiri dari tiga generasi semakin mengalami penurunan.

Salah satu ciri khas masyarakat industri adalah beralihnya mata pencaharian dari bidang pertanian ke industri modern, dengan bekerja pada suatu industri tertentu, dan menerima gaji setiap bulannya dalam jumlah tertentu. Pada keluarga yang mempunyai anak, pendidikan untuk anak tidak lagi diajarkan sepenuhnya di dalam keluarga, melainkan telah dialihkan ke sekolah-sekolah sejak anak menginjak usia taman kanak-kanak.

\subsection{Anak Sebagai Barang Konsumsi}

Konsep kedua yang dipaparkan oleh Leibenstein adalah anak sebagai barang konsumsi. Konsumsi yang dimaksud kemudian dibagi lagi menjadi dua bagian, yaitu konsumsi langsung dan konsumsi tidak langsung, yang dimaksud dengan konsumsi langsung adalah segala biaya yang habis digunakan untuk membesarkan anak, sedangkan konsumsi tidak langsung adalah biaya yang hilang akibat terhentinya pendapatan dari wanita yang harus berhenti bekerja akibat melahirkan anak.
Besarnya pengeluaran rumah tangga dapat terlihat dari jumlah anggota keluarga yang terdapat di dalamnya. Jumlah pengeluaran pun berbeda-beda berdasarkan usia seseorang, bagi keluarga yang mempunyai anak, usia anak turut pula mempengaruhi besarnya pengeluaran rumah tangga. Seorang anak yang baru dilahirkan mempunyai kebutuhan yang lebih besar dibandingkan dengan anak yang telah memasuki usia sekolah. Hal ini disebabkan karena pada usia 0 sampai dengan 3 tahun, seorang anak harus mendapatkan dukungan akan perawatan dan kesehatan yang baik.

Data yang akan digunakan dalam subbab ini diambil dari Family Income and Expenditure Survey. Berdasarkan data yang ada, kisaran biaya yang dibutuhkan untuk membesarkan anak sejak umur 0 sampai dengan 18 tahun adalah sebanyak 17 juta Yen. Jumlah ini belum termasuk dengan biaya yang diperlukan pada saat anak memasuki usia pendidikan tingkat tinggi (Hori, 2011: 3-9). Dari data yang ada, Family Income and Expenditure Survey mengkategorikan pengeluaran dalam membesarkan anak hanya sampai anak berusia 18 tahun, hal ini disebabkan seorang anak cenderung untuk tinggal terpisah dengan orangtua mereka ketika menempuh pendidikan tinggi.

Tabel 2. Akumulasi Pengeluaran dalam Membesarkan Anak Usia 0 s.d 18 Tahun

\begin{tabular}{|c|c|c|}
\hline & \multicolumn{2}{|c|}{ ( x 1000 Yen ) } \\
\hline Kategori & $\begin{array}{c}\text { Anak } \\
\text { Laki-laki }\end{array}$ & $\begin{array}{c}\text { Anak } \\
\text { Perempuan } \\
\end{array}$ \\
\hline Pangan & 4.887 & 4.526 \\
\hline $\begin{array}{c}\text { Gas, Listrik dan } \\
\text { Air }\end{array}$ & 979 & 949 \\
\hline Perabotan Rumah & 415 & 318 \\
\hline Sandang & 1.006 & 1.342 \\
\hline $\begin{array}{l}\text { Obat dan } \\
\text { Kesehatan }\end{array}$ & 804 & 781 \\
\hline $\begin{array}{c}\text { Transportasi dan } \\
\text { Komunikasi }\end{array}$ & 1.250 & 1.235 \\
\hline Pendidikan & 4.622 & 4.585 \\
\hline Rekreasi & 2.524 & 2.854 \\
\hline Total & 16.547 & 16.593 \\
\hline
\end{tabular}


Sumber: Family Income and Expenditure Data ( 2004-2008 )

Family Income and Expenditure Survey, hanya menggolongkan biaya untuk membesarkan anak sampai ketika anak berusia 18 tahun. Hal ini disebabkan umumnya seorang anak yang menempuh pendidikan tinggi akan memilih untuk tinggal terpisah dengan orangtua mereka. Kelemahan dari data ini adalah Family Income and Expenditure Survey hanya mengkategorikan pengeluaran rumah tangga selama anggota keluarga yang bersangkutan tetap tinggal dalam rumah yang sama.

Dari data di atas, dapat diketahui bahwa rata-rata pengeluaran yang dibutuhkan untuk membesarkan anak sejak berusia 0 sampai dengan 18 tahun berkisar 16.570.000 Yen. Dari kategori yang dijabarkan, jumlah pengeluaran yang paling tinggi terjadi pada kategori pangan dan pendidikan. Jumlah tersebut belum termasuk dalam biaya yang dibutuhkan ketika anak memasuki pendidikan di universitas, karena umumnya seorang anak akan tinggal terpisah dari orang tuanya ketika mereka menempuh pendidikan di universitas.

Grafik 3.Alasan untuk tidak mempunyai anak dalam jumlah ideal (2002)

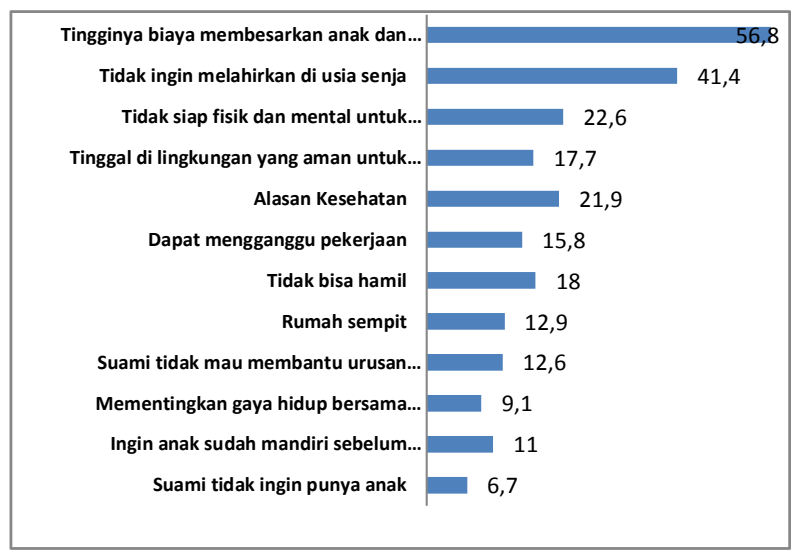

Sumber: National Institute of Population and Social, Security Research's Japanese National Fertility Survey 2002
Berdasarkan hasil survey yang dilakukan pada tahun 2002 mengenai alasan masyarakat Jepang untuk tidak memiliki anak dalam jumlah ideal, dapat terlihat bahwa mayoritas menjawab "Tingginya biaya membesarkan anak " merupakan alasan yang paling tinggi. Di susul dengan alasan mayoritas kedua yaitu "tidak ingin melahirkan di usia senja”. Dengan demikian dapat terlihat bahwa faktor ekonomi menjadi alasan terbesar yang melatarbelakangi masyarakat Jepang untuk memilih memiliki anak dalam jumlah ideal.

\subsection{Anak Sebagai Sumber Kenyamanan}

Konsep anak sebagai sumber kenyamanan lahir dari harapan orangtua yang mempunyai anak dengan tujuan bahwa anak adalah tempat mereka bergantung ketika mereka memasuki usia lansia. Secara ekonomi, orangtua yang telah memasuki usia lanjut akan bergantung kepada anak mereka, hal ini disebabkan usia lansia bukanlah termasuk dalam golongan usia produktif.

Dalam sebuah jajak pendapat yang dilakukan oleh Mainichi National Family Planning pada tahun 1990, diajukan sebuah pertanyaan tentang "apakah untungnya memiliki anak?” sebanyak $1 \%$ menjawab anak memberikan kontribusi pada keluarga, 9\% menjawab anak sebagai tempat bergantung orang tua ketika memasuki usia senja, $1 \%$ menjawab anak sebagai penerus usaha keluarga yang masih mengindikasikan bahwa anak sebagai sumber ketentraman ketika orang tua memasuki usia senja. 16\% menjawab anak sebagai penerus garis keluarga, $73 \%$ menjawab anak akan memberikan warna dalam kehidupan berkeluarga, dan hanya 8\% yang menjawab bahwa mengasuh dan membesarkan anak adalah sesuatu yang sangat menyenangkan (Ogawa, 1993: 732).

Jika mengacu pada kondisi yang tertuang pada pernyataan di atas, maka pernyataan ketiga yang dikemukakan oleh Leibenstein mengenai konsep anak sebagai sumber kententraman, tidak sesuai dengan yang terjadi pada masyarakat Jepang. 


\section{Kesimpulan}

Fenomena shoushika yang terjadi di Jepang telah berlangsung sejak tahun 1975, namun istilah ini baru muncul pertama kali pada tahun 1992, setelah pemerintah Jepang dikejutkan oleh rendahnya jumlah kelahiran pada tahun 1989. Hingga saat ini jumlah kelahiran di Jepang terus mengalami penurunan, dan meskipun pada tahun 2006 dan 2007 TFR Jepang sempat mengalami kenaikan, namun jumlahnya tidak menunjukkan angka yang signifikan, dan masih berada di bawah jumlah kelahiran ideal dalam suatu negara.

Penelitian ini menggunakan teori ekonomi fertilitas yang telah dipaparkan sebelumnya oleh Leibenstein. Leibenstein mengungkapkan bahwa terdapat tiga konsep anak. Konsep pertama adalah anak sebagai sumber produksi yang bertujuan untuk mendukung pendapatan keluarga, hal ini umumya terjadi pada masyarakat pertanian yang mengandalkan manusia sebagai tenaga kerja. Konsep kedua adalah anak sebagai konsumsi, yang sangat dekat dengan teori yang sebelumnya dipaparkan oleh Becker. Konsumsi yang di maksud adalah segala bentuk pengeluaran keluarga yang dibutuhka untuk membesarkan anak. Konsep anak yang ketiga adalah anak sebagai sumber kenyamanan, yang sangat erat kaitannya dengan kebutuhan orang tua untuk bergantung pada anak mereka ketika memasuki usia lanjut. Hal ini disebabkan karena pada usia lanjut, seseorang sudah tidak lagi dikategorikan sebagai usia produktif.

Dengan meminjam teori yang sebelumnya dipaparkan oleh Leibenstein, maka diketahui bahwa telah terjadi perubahan konsep anak pada masyarakat Jepang yang menimbulkan meningkatnya fenomena shoushika. Masyarakat Jepang memandang anak tidak lagi memiliki nilai produksi ataupun sumber kenyamanan, melainkan memiliki nilai konsumsi. Seorang anak harus diberikan fasilitas dan didukung dengan baik untuk menjadi SDM yang berkualitas, lewat penyediaan pendidikan berkualitas sejak usia dini.

Tingginya biaya untuk membesarkan anak menjadi salah satu faktor yang menjadi latar belakang masyarakat Jepang untuk tidak memiliki anak dalam jumlah ideal yang ditetapkan dalam menjaga stabilitas ketersediaan SDM. Tentunya, hal ini menjadi tantangan bagi masyarakat Jepang pada beberapa tahun ke depan, dalam menjaga kondisi pertumbuhan populasi natural.

\section{DAFTAR PUSTAKA}

\section{BUKU}

Coulmas, Florian. 2007. Population Decline and Ageing in Japan - the Social Consequences. New York : Routledge

\section{JURNAL ILMIAH}

Hori, Masahiro. 2011. The Expenditure on Children in Japan. Tokyo : Economic and Social Research Institute, Cabinet Office

Leibenstein, H. 1974. An Intrepretation of the Economic Theory of Fertility Promising Path or Blind Alley.
Yamada, Masahiro. 2008. Shoushika Shakai Nihon : Mou Hitotsu no Kakusa no Yukue. Japan : Iwanami Shinsho

Journal Economic Literature, Vol 12, No.2

Ogawa, Naohiro and Robert D. Retherford. 1993. The Resumption of Fertility Decline in Japan. 1973-1992. Population Council : Population and Development Review, Vol 19, No.4 hlm 703-741. www.jstor(2938411), 
Izumi, Volume 5, No 1, 2016

e-ISSN: 2502-3535, p-ISSN: 2338-249X

Tersedia online di http://ejournal.undip.ac.id/index.php/izumi

Ozawa, Martha N et.al. 1995. Child WellBeing in Japan The High Cost of Economic Succes. UNICEF, International Child Development Centre
Retherford, Robert D, Naohiro Ogawa, and Satomi Sakamoto. 1996.. Population Investigation Committee. www.jstor.org/stable/2175027 Values and Fertility Change in Japan

Ueno, Chizuko. 1998. The Declining Birthrate : Whose Problems?. Review of Population and Social Policy, No.7

\section{LAPORAN}

National Institute Population and Social Security Research. 1997

\section{PUSTAKA INTERNET}

www.stat.go.jp/english/data/handbook/co2cont.htm

www.stat.go.jp/english/data/zensho/1999/2.htm

www.mext.go.jp/b_menu/hakusho/html/hpab200901/detail/1305849.htm 